UDC 811.113.6, 811.111

Natalia Linevich

Immanuel Kant Baltic Federal University

\title{
REQUESTS IN SWEDISH AND ENGLISH IN TERMS OF POLITENESS
}

For citation: Linevich N. Requests in Swedish and English in terms of politeness. Scandinavian Philology, 2019, vol. 17, issue 2, pp. 234-246. https://doi.org/10.21638/11701/spbu21.2019.203

The paper deals with the analysis of request patterns in Swedish and English both in terms of their differences and similarities. The present research is mainly based on P. Brown and S. Levinson's politeness theory $(1978,1987)$ as well as the model of social differentiation elaborated by W.Labov, A. Shveizer and V.Zabotkina. The latter is built on two axes of social differentiation of language: stratificational and situational. On the stratificational axis the analysis is carried out taking into account one of the three pragmatic parameters, namely the socio-economic one, where education is one of the crucial criteria for the present paper. The gender and age parameters are outside the scope of this paper. On the situational axis, the role relationships of the interlocutors (symmetric/asymmetric) and the tonality of the situation (official/unofficial) are taken into account. The data for this analysis came from a discourse questionnaire, which consisted of 3 situations requiring requests, and was filled by 50 Swedish and 50 Russian respondents. The following classification has been proposed based on two criteria: 1) the indirectness of the utterances and 2) speaker-hearer -oriented formulas. As a result of the analysis, it becomes obvious that the realization of request patterns in the languages in question occurs mainly with the help of negative politeness strategies modifying their imposition. The speakers tend to use indirect hearer-oriented constructions (questions), semantic minimization, as well as impersonalization. Interrogatives on high-deference level of politeness are characteristic of persons with University degree (UD) in both languages, while statements on low-deference level of politeness are characteristic of representatives without University degree. However, the indirectness of utterances in the languages in question differs. The Swedish language is characterized by the fewer number of politeness strategies per utterance, which lowers its indirectness compared to the English language. The parameter of speaker-heareroriented formulas appeared not to be the leading one in the undertaken research.

Keywords: politeness strategies, semantic minimization, impersonalization, speaker-hearer-oriented formulas, interrogatives, requests. 
The decision to investigate requests is based on the idea that when people make requests, they initiate a "negotiation process", the outcome of which will be according to Durst-Andersen either "signing or not signing a contract" [Durst-Andersen, 2011]. Request is considered to be one of the most threatening speech acts as it is performed in the interest of the speaker and at the cost of the hearer [Brown, Levinson, 1987]. Typical representatives of languages oriented towards the hearer are the Scandinavian languages and English. Thus, it will be interesting to conduct a study of the request patterns in the two languages, both in terms of their differences and similarities.

The data for our analysis came from a discourse questionnaire, which consisted of 3 situations requiring requests, and was filled by 50 Swedish and 50 English respondents. At the first stage of the analysis, we identified the formulas proposed by the majority of respondents, and defined the level of politeness reflected in these formulas (high-deference, middeference and low-deference). In situation 1 the respondent had to ask the professor to open the window during the lecture. The analysis of the results did not reveal significant differences between Swedish and English. This communicative situation is assessed as violating the principle of politeness by representatives of both cultures. So, a 29-year-old young English female respondent with University degree (w UD) considered it inappropriate and unacceptable to make such a request to the professor and thereby violate the studying process: "Realistically I would probably not disturb the whole class by doing this but for the sake of argument I might put up my hand and say: Excuse me but would you mind opening the window a small crack? It's quite warm in here". Given a specific situation, speakers can select from among a variety of forms of request ranging from the direct and straightforward to the mildly or strongly indirect. According to Searle, politeness is held to be a chief motivation for indirectness [Searl, 1975]. Thus, indirect requests have a strong relationship to politeness. Nobody would deny that making a request in a bald manner by using a pure imperative is an imposition and extremely impolite in English [Brown, Levinson, 1987]. The example above illustrates an elaborate hearer-oriented interrogative construction where the speaker employs the following distance strategies: "be conventionally indirect", "apologize" and "minimize the imposition" (using the diminutive "a small crack").

The same approach is shared by the Swedish respondent with University degree of 24 years, who considers it inappropriate and unaccep- 
table to make a similar request to the professor, thereby violating the learning process. He would formalize his request through a detailed speaker-oriented statement: Ursäkta, det är jättevarmt är inne. Går det bra om jag öppnar fönstret? [Sorry, it's very hot here. Is it OK if I open the window?].

According to our data, both Swedish and English respondents tend to prefer indirect requesting strategies such as interrogatives in situation 1 as $100 \%$ of the answers of the English and Swedish respondents in this situation were indirect questions. Our conclusion with respect to English respondents confirm the results of the empirical cross-linguistic study of directives conducted by Olga Rykova Ibsen in English, Russian and Danish [Rykov Ibsen, 2016, p. 195].

The politeness of indirect questions is explained by the fact that they make it easier for the hearer to reject, provide an opportunity not to perform the action to which he/she is forced, but what is more important, they demonstrate the speaker's respect for the hearer's independence [Larina, 2009, p. 217].

The most frequent form for the request both in Swedish and English is a question with a modal verb (81\% of Swedish answers and $95 \%$ of English answers).

Based on the variety of the received data we offer our classification built on two parameters: 1) the indirectness of the utterances and 2) speaker-hearer-oriented formulas. According to the first parameter we distinguish the following most frequent syntactic patterns:

\begin{tabular}{|c|c|}
\hline Swedish & English \\
\hline $\begin{array}{c}\text { 1) speaker-based indirect utterance (mo- } \\
\text { dal verb kan + negation +/- } \\
\text { politeness modifier fä) } \\
\text { Kan vi inte öppna ett fönster? } \\
\text { Kan vi inte fä öppna fönstret? }\end{array}$ & $\begin{array}{c}\text { 1) hearer-based indirect utterance } \\
\text { (modal verb can + politeness modifier } \\
\text { please) }\end{array}$ \\
$\begin{array}{c}\text { Can you open the window please? } \\
\text { 2) hearer-based indirect utterance } \\
\text { (modal verb kan + politeness modifier } \\
\text { är du snäll) }\end{array}$ & $\begin{array}{c}\text { 2) hearer-based indirect utterance } \\
\text { (modal verb could + politeness marker } \\
\text { please) }\end{array}$ \\
$\begin{array}{c}\text { Kan du öppna fönstret är du snäll? / Kan } \\
\text { du vara snäll och öppna fönstret? / Kan du } \\
\text { öppna fönstret en liten stund? }\end{array}$ & \begin{tabular}{c} 
Could you please open the window? \\
\hline
\end{tabular} \\
\hline
\end{tabular}




\begin{tabular}{|c|c|}
\hline Swedish & English \\
\hline $\begin{array}{c}\text { 3) impersonal construction (modal verb } \\
\text { skulle+ infinitive) }\end{array}$ & $\begin{array}{c}\text { 3) speaker-oriented indirect utterance } \\
\text { (modal verb could + politeness marker } \\
\text { please) }\end{array}$ \\
$\begin{array}{c}\text { Skulle det gå bra att öppna fönstret? / } \\
\text { Skulle det vara tänkbart att öppna fönstret } \\
\text { för vädring en stund? } \\
\begin{array}{c}\text { Skulle det kunna gå att öppna fönstret en } \\
\text { stund? }\end{array}\end{array}$ & $\begin{array}{c}\text { Could we have some air, please? } \\
\text { Could we please have a window opened? }\end{array}$ \\
\hline $\begin{array}{c}\text { 4) hearer-oriented indirect utterance } \\
\text { (modal verb skulle + infinitive } \\
\text { kunna+ politeness modifier är du snäll) } \\
\text { Skulle du kunna öppna fönstret är du snäll? }\end{array}$ & $\begin{array}{c}\text { W) hearer-oriented indirect utterance } \\
\text { (modal verb would) }\end{array}$ \\
\hline
\end{tabular}

Our data demonstrate that the prevailing syntactic structure in the answers of the Swedish respondents with UD was structure 4 on highdeference level in our classification. For example: Skulle du kunna öppna fönstret är du snäll? [Could you be so kind to open the window, please?]. Then follows structure No. 3: Skulle det gå bra att öppna fönstret ett tag? [Would it be OK to open the window for a while?]. Structure No. 2 takes the third place and was equally employed by the respondents of both groups regardless of their education: Kan du öppna fönstret är du snäll? I Kan du vara snäll och öppna fönstret? / Kan du öppna fönstret en liten stund? [Can you please open the window?]. At the same time, the second most frequently used structure among the respondents with UD was structure No. 1 on low-deference level in our classification: Kan vi inte öppna ett fönster?/ Kan vi inte fä öppna fönstret? [Can’t we open the window?].

The predominant syntactic structure in the answers of the English respondents with UD was also structure No. 4 at high-deference level. For example: Would you mind opening the window / if we had the window open please / if I open the window please? $40 \%$ of the respondents have employed it in their answers. This is followed by structure No. 2, employed by $27 \%$ of the respondents within this group. For example: Could you please open the window? Structure No. 3 turned out to be unmarked as it was equally used by $27 \%$ of all English respondents irrespective of their education. For example: Could we have some air / a window opened please? Structure No. 1 on low-deference level was used mainly by the respondents without UD. 
The mere fact that the answers of the Swedish respondents with UD coincide with the answers of the respondents without UD, while the answers of the English respondents with UD differ from the answers of the respondents without UD, as well as our observation that the syntactic structure on low-deference level of politeness is employed by the Swedish respondents with UD make us draw an additional conclusion that in Swedish the neutral level of politeness is shifted towards the low level, i. e., towards informal politeness whereas in English it is shifted towards the formal one.

Based on speaker-hearer perspective, we distinguish two main types of interrogative utterances:

1) object-oriented, i. e. hearer-oriented:

Sw. Kan du öppna fönstret en liten stund? [Can we open the window for a while?]

Eng. Can you open the window please?

2) subject-oriented, i. e. speaker-based:

Sw. Skulle vi kunna öppna fönstret? [Would we be able to open the window?]

Eng. Could we have some air in this class please?

It is noteworthy to mention that both in Swedish and English the second type is mainly used to dissociate the hearer from the discourse in order to minimize the imposition, thus making the utterance sound more polite.

Based on the above-mentioned parameter, the results of our study are presented in the table below.

\begin{tabular}{|c|c|c|}
\hline & Swedish & English \\
\hline $\begin{array}{l}\text { S } \\
\text { 疍 } \\
3\end{array}$ & $\begin{array}{l}\quad \text { object-oriented - } 40 \% \\
\text { Skulle du kunna öppna fönstret } \\
\text { är du snäll? [Could you open the } \\
\text { window, please?] } \\
\text { Kan du öppna fönstret är du snäll?/ } \\
\text { Kan du vara snäll och öppna fönstret? } \\
\text { [Can you open the window, please?] } \\
\quad \text { subject-oriented - } 28.5 \% \\
\text { Det är så varmt skulle vi kunna } \\
\text { öppna fönstret? [So hot, could we } \\
\text { open the window?] } \\
\text { Kan vi inte få öppna fönstret [Can't } \\
\text { we open the window?] }\end{array}$ & $\begin{array}{l}\quad \text { object-oriented - } 50 \% \\
\text { Would you / Could you mind opening } \\
\text { the window? } \\
\quad \text { subject-oriented }-20 \% \\
\text { Could we please have a window } \\
\text { opened? } \\
\text { Could we have some air, please? } \\
\text { object-subject-oriented - } 20 \% \\
\text { Would you mind if I open the window } \\
\text { please? } \\
\text { Would you mind if we had the window } \\
\text { open please? }\end{array}$ \\
\hline
\end{tabular}




\begin{tabular}{|c|c|c|}
\hline & Swedish & English \\
\hline 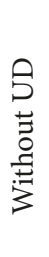 & $\begin{array}{l}\quad \text { object-oriented }-66.6 \% \\
\text { Kan du öppna fönstret en liten } \\
\text { stund? [Can you open the window } \\
\text { for a while?] } \\
\quad \text { subject-oriented }-33.3 \% \\
\text { Ska vi öppna fönstret? [Shall we } \\
\text { open the window?] }\end{array}$ & $\begin{array}{c}\text { object-oriented }-50 \% \\
\text { Can you open the window please? } \\
\text { subject-oriented }-50 \% \\
\text { Could we have some air, please? }\end{array}$ \\
\hline
\end{tabular}

The above-mentioned parameter (subject-object) appeared not to be the leading one in this particular communicative situation (No. 1). On the contrary, we can state that there are more similarities than differences in the languages in question. We can't but mention the combined hearer-oriented structure found only in English presented by an indirect utterance and appealing to the speaker's ability to fulfill the request:

Would you mind if I open the window please?

Let us analyze what politeness strategies and language means are employed performing requests in the languages in question taking into account the above-mentioned parameters and the level of education of our respondents.

Strategies of independence (negative politeness strategies in the theory of P. Brown and S. Levinson) like "be conventionally indirect", "questions, hedge" are used in all Swedish and English answers regardless of the level of education of our respondents. Besides, $24 \%$ of the Swedish respondents with UD and $60 \%$ of the English ones within the same group use "the apologize strategy":

Sw. Ursäkta, det är väldigt varmt här. Jag undrar om vi kunde öppna ett fönster? [Sorry, it's very hot here. I wonder if we could open the window?] here?

Eng. Excuse me, could you please open the window, it's rather hot in

The "be pessimistic" strategy (using conditionals) is employed by $51.5 \%$ Swedish respondents, whereas in the English answers this figure corresponds to $93 \%$. 


\begin{tabular}{|l|l|}
\hline \multicolumn{1}{|c|}{ Swedish } & \multicolumn{1}{|c|}{ English } \\
\hline \multicolumn{2}{|c|}{ Respondents with UD } \\
\hline $\begin{array}{l}\text { Skulle du kunna öppna fönstret är du } \\
\text { snäll? [Would you be able to open the } \\
\text { window, please?] } \\
\text { Skulle vi inte kunna öppna fönstret? } \\
\text { [Wouldn't we be able to open the win- } \\
\text { dow?] }\end{array}$ & $\begin{array}{l}\text { Excuse me, could you please open the } \\
\text { window, it's rather hot in here? } \\
\text { Could you open the window please? }\end{array}$ \\
\hline \multicolumn{2}{|c|}{ Respondents without UD } \\
\hline $0 \%$ & $\begin{array}{l}\text { Could we have some air in this class } \\
\text { please? }\end{array}$ \\
\hline
\end{tabular}

The "minimize the imposition" strategy is equally used both by the Swedish respondents (en liten stund, ett tag, lite, en stund) [for a moment, a little, a bit] and the English ones (a small crack, any chance, some, a bit, a little) in $60 \%$ of all utterances, regardless of the level of education.

\begin{tabular}{|l|l|}
\hline \multicolumn{1}{|c|}{ Swedish } & \multicolumn{1}{|c|}{ English } \\
\hline \multicolumn{2}{|c|}{ Respondents with UD } \\
\hline $\begin{array}{l}\text { Är det OK att öppna fönstret lite? [Is it } \\
\text { OK to open the window a bit?] }\end{array}$ & $\begin{array}{l}\text { Excuse me but would you mind opening the } \\
\text { window a small crack? } \\
\text { Would you mind opening the window a bit? }\end{array}$ \\
\hline \multicolumn{2}{|c|}{ Respondents without UD } \\
\hline $\begin{array}{l}\text { Kan du öppna fönstret en liten stund? } \\
\text { [Can you open the window for a little } \\
\text { while] }\end{array}$ & Could we have some air in this class please? \\
\hline
\end{tabular}

The "impersonalize the speaker and hearer" strategy is employed by $24 \%$ of all Swedish respondents irrespective of their education and by $10 \%$ of the English respondents with UD. The strategy in question is mainly presented by passive voice and impersonal constructions:

Sw. Är det OK att öppna fönstret lite? [Is it OK to open the window a little?] Eng. Would it be ok to have the window open? 
Our data demonstrate that apart from the negative strategies our respondents use the positive politeness strategy, namely "include both speaker and hearer in the activity".

\begin{tabular}{|l|l|}
\hline \multicolumn{1}{|c|}{ Swedish } & \multicolumn{1}{|c|}{ English } \\
\hline \multicolumn{2}{|c|}{ Respondents with UD } \\
\hline $\begin{array}{l}\text { Jag undrar om vi kunde öppna ett fönster } \\
{[\text { I wonder if we could open a window] }} \\
24,1 \%\end{array}$ & $\begin{array}{l}\text { Any chance we could have the window } \\
\text { opened? - 33 \% } \\
\text { Could we please have a window opened? } \\
20 \%\end{array}$ \\
\hline \multicolumn{2}{|c|}{ Respondents without UD } \\
\hline $\begin{array}{l}\text { Ska vi öppna fönstret? [Shall we open the } \\
\text { window?] - 50 \% }\end{array}$ & $\begin{array}{l}\text { Could we have some air in this class } \\
\text { please? }\end{array}$ \\
\hline
\end{tabular}

As it is shown in the table above the latter strategy is mostly used by the respondents without UD both in Swedish and English.

Based on our analysis we have come up with the following observation. The number of politeness strategies used by our respondents per utterance correlate with their level of education. The respondents with UD use more politeness strategies per utterance. This tendency is more typical for English. The number of politeness strategies in Swedish answers vary mainly from one to two.

Cf. Sw. Skulle du vilja öppna fönstret? [Would you like to open the window?]

The Swedish answer contains only two strategies: "be conventionally indirect and "be pessimistic."

Eng. Excuse me but would you mind opening the window a small crack? It's quite warm in here.

We can observe four strategies in the answer above: 1) "be conventionally indirect," 2) "be pessimistic", 3) "apologize," 4) "minimize the imposition."

Our results confirm the observation of T. V. Larina that "the more strategies are employed in the utterance, the more indirect this utterance is ... thus increasing the level of politeness" [Larina, 2009, p. 230].

In situation 2 an asymmetric type of relationship is introduced when the subordinate respondent asks his boss to borrow the book. Here we 
can highlight one more pattern that was not presented in the previous answers and typical of the English respondents with UD. This pattern is characterised by the highest ranking in our classification and presented by a subject-oriented interrogative appealing to hearer's ability to fulfil the request. In English this pattern is typical for high-deference level and can be easily identified by shifting the time plan (past tense):

I was wondering if I could borrow it for a bit to help me with some research I'm doing?

The following negative politeness strategies are employed in this speaker-oriented answer (use of a personal pronoun $I$ instead of you): 1) "be conventionally indirect", 2) "question, hedge", 3) "be pessimistic", 4) "minimize the imposition" (for a bit).

Our data demonstrate that the dominant syntactic structure in the Swedish respondents' answers, regardless of educational level, was structure No. 2 on low-deference level in our classification and is represented by the construction of "modal verb kan $+/$ - politeness modifier få”. For example: Kan jag få låna boken $x x x$ ? [Can I borrow the book...?]. This observation allows us to conclude that structure No. 2 is an unmarked means of making requests in Swedish emphasizing neutral politeness. Then comes speaker-oriented structure No. 4 within the answers of the respondents with UD: Skulle jag kunna få lana boken av dig? [Would I be able to borrow the book from you?]. The third place is taken by another syntactic structure which was not introduced before and formed of an indirect question with Jag undrar [I wonder]) + modal verb skulle:

Jag undrar om jag skulle kunna få låna din bok om... [I wonder if I could borrow your book if...].

In English the dominant syntactic structure in the respondents' answers, regardless of the level of education, was structure No. 3, which is represented by a modal verb in the subjunctive mood and a politeness modifier please. For example: Could I borrow [book] for a few days please? / Could I possibly borrow it please? The prevailing syntactic structure in the answers of the English respondents without UD was structure No. 1, which undergoes a slight modification due to the asymmetry of the situation. In the responses of the representatives of the latter group, the "withdraw the hearer from the discourse" strategy is em- 
ployed, shifting the communicative focus from the hearer to the speaker himself, for example: Can I borrow your book please?

Based on subject-object criterion, speaker-oriented utterances take a leading place in both languages, as more polite, which seems quite logical, given the asymmetry of the situation ("bottom-up"). Thus, the proportion of Speaker-oriented answers in the Swedish language was $80 \%$, in English - 87.5\%. This observation allows us to state that there is a tendency to use the "withdraw the hearer from the discourse" strategy in asymmetric situations ("bottom-up") in both languages.

The third communicative situation also refers to the asymmetric type of situation when the boss turns to his subordinate with a certain request. In this case, the vector of subordination changes, and communication takes a downward direction.

In Swedish the dominant syntactic structure in the respondents' answers, regardless of the level of education, is structure No. 4, which stands for high-deference level in our classification and is introduced by modal verb skulle + infinitive kunna. For example: Skulle du kunna köpa några frimärken åt mig? [Would you be able to buy me some stamps?] Then comes structure No. 2, regardless of educational level, and introduced by a modal verb kan +infinitive without politeness modifier är du snäll [please]: Kan du köpa några frimärken till mig? [Can you buy some stamps for me?] Our data show that structures No. 2 and No. 4 are unmarked means of making request in an asymmetrical situation when boss turns to subordinate in Swedish. In other words, the socio-economic parameter is not a leading one in this communicative situation.

As for English, the dominant syntactic structure in the answers of the English respondents with UD was structure No. 2, introduced by a modal verb could and a politeness modifier please. For example: Could you please do me a favour and get me some stamps?

We can't but point out the use of the evaluative adjective huge in the answer of a female English respondent with UD: Could you do me a huge favour and pick me up a pack too please? It is obvious that we have to do with exaggeration on the speaker's part as it was given in the situation that the subordinate was on his way to fix his own purchase. However, this answer implies the sincere desire of the speaker to please the hearer [Brown, Levinson, 1987, p. 101]. Thus, apart from the negative strategies such as "be conventionally indirect" and "question, hedge" 
the positive strategy of the "exaggerate", implying interest, approval and sympathy with hearer are being employed in the answer in question.

Our Swedish data do not demonstrate any similar use of the above mentioned positive strategy.

It is only in this communicative situation where we come across a single use of a direct explicit way of making requests in English by a respondent without UD through an imperative model: Get me fags when you are there. This example is interesting as it confirms the classical view that such polite imperatives are usually used with informal vocabulary [Aijmer, 1996, p. 85]. Direct style of communication can be explained by informality that representatives without UD aspire to.

Based on subject-object oriented criterion, we did not find any difference in the languages in question, which seems quite logical, given the downward vector of the communicative situation.

Our data show that level of education determines linguistic means of making requests in the languages in question. Thus, the higher education the respondent possesses the higher deference level his/her utterance appear to be on. As for the difference between the compared languages it lies in indirectness of utterances. The Swedish language is characterized by a fewer number of politeness strategies per utterance, which significantly lowers its indirectness compared to the English language. The observation that the answers of Swedish respondents with UD coincide with the answers of respondents without UD, whereas the answers of English respondents differ depending on the level of education, as well as the fact that the syntactic structure with low-deference level is highlighted among the answers of Swedish respondents with UD make us draw a conclusion that in Swedish the neutral level of politeness is shifted towards the low level, i. e., towards informal politeness whereas in English it is shifted towards the formal one. The subjectobject parameter appeared not to be the leading one in the communicative situations we examined. On the contrary, it showed that the two languages under consideration have more similarities than differences.

\section{REFERENCES}

Aijmer K. Conversational routines in English: Convention and creativity. Routledge, 1996. $268 \mathrm{p}$.

Brown P., Levinson, S. C. Politeness, some universals in language usage. Cambridge: Cambridge University Press, 1987. 345 p. 
Chekalina E. M. What happened and is happening in modern Swedish? Skandinavian Philology. 1999. No. 6. P. 35-46. (In Russian)

Durst-Andersen P. Lingusitic supertypes: a cognitive-semiotic theory of human communication. Berlin; New York: Walter de Gruyter, 2011. $314 \mathrm{p}$.

Larina T. V. Category of Politeness and Communication Style: Comparison of English and Russian Linguistic and Cultural Traditions. Moscow, 2009. 512 p. (In Russian)

Rykov Ibsen O. An empirical cross-linguistic study of directives. A semiotic approach to the sentence forms chosen by British, Danish and Russian speakers in native and ELF contexts. Doctoral dissertation in Intercultural Business Communication. Copenhagen Business School, 2016. 358 p.

\section{Наталья Линевич}

Балтийский федеральньй университет им. И. Канта

\section{ВЫРАЖЕНИЕ ПРОСЬБЫ В ШВЕДСКОМ И АНГЛИЙСКОМ ЯЗЫКАХ С ТОЧКИ ЗРЕНИЯ ТЕОРИИ ВЕЖЛИВОСТИ}

Для цитирования: Linevich N. Requests in Swedish and English in terms of politeness // Скандинавская филология. 2019. Т. 17. Вып. 2. С. 234-246. https://doi.org/10.21638/11701/spbu21.2019.203

Статья посвящена анализу языковых средств выражения просьбы в шведском и английском языках с учетом стратегий вежливости. Теоретическую базу исследования составили ставшие классикой работы П. Браун и С. Левинсона, а также модель социальной дифференциации языка У. Лабова - А. Швейцера В.Заботкиной, в основе которой лежит взаимодействие стратификационной и ситуативной осей вариативности языка. По стратификационной оси в рамках данной статьи анализ проводился с учетом одного из трех прагматических параметров, а именно социально-экономического, где мы выделяем критерий «уровень образования». Гендерный и параметр возраста остались за рамками статьи. По ситуативной оси принимались во внимание ролевые отношения участников коммуникации (симметричные/асимметричные), тональность ситуации (официальная/неофициальная). Материалом для исследования послужили данные анкетирования, проведенного среди 100 информантов (50 шведов и 50 англичан). Для сопоставления полученных результатов была предложена классификация, исходя из двух параметров: 1) степень вежливости вопросов и 2) субъектно-объектная ориентированность. В результате проведенного анализа становится очевидно, что вербализация просьбы в рассматриваемых языках происходит главным образом с помощью стратегий негативной вежливости, языковой репрезентацией которых являются косвенный характер высказываний, семантическая минимизация, а также имперсонализация (безличные конструкции, употребление обобщающего «мы»). Вопросительные высказывания с наибольшей степенью вежливости характерны для представителей с высшим образованием, в то время как высказывания с наименьшей степенью - для представителей без высшего образования. Однако косвенность высказываний в рассматриваемых языках будет отличаться. Для шведского языка характер- 
но использование меньшего количества стратегий в одном высказывании, что существенно понижает его косвенность по сравнению с английским языком. Параметр субъектно-объектной ориентированности не явился ведущим в рассмотренных коммуникативных ситуациях при сравнении ответов респондентов в шведском и английском языках.

Ключевые слова: стратегии вежливости, семантическая минимизация, имперсонализация, субъектно-объектная ориентированность, косвенные вопросы, просьба.

\author{
Natalia Linevich \\ Senior lecturer, \\ Immanuel Kant Baltic Federal University, \\ 14, ul. A. Nevskogo, Kaliningrad, 236016, Russia \\ E-mail: natalia.kgd@gmail.com
}

\author{
Линевич Наталья Юрьевна \\ старший преподаватель, \\ Балтийский федеральный университет им. И. Канта, \\ Россия, 236016, Калининград, ул. А. Невского, 14 \\ E-mail: natalia.kgd@gmail.com
}

Received: August 15, 2019

Accepted: October 7, 2019 